\title{
THE EFFECT OF DIRECT COMPENSATION TOWARDS EMPLOYEE PERFORMANCE IN FRONT OFFICE DEPARTMENT AT ST. REGIS BALI RESORT
}

\author{
Anak Agung William Vikha Nanda \\ Politeknik Pariwisata Bali \\ w.vikhananda@gmail.com \\ Nyoman Gde Dewa Rucika \\ Politeknik Pariwisata Bali \\ w.vikhananda@gmail.com \\ Mahendra Adi Winatha
Politeknik Pariwisata Bali
w.vikhananda@gmail.com \\ Hilda Apriani \\ Politeknik Pariwisata Bali \\ w.vikhananda@gmail.com
}

\begin{abstract}
Analyzing the effect of direct compensation towards em ployee performance is essential forevery business especially hospitality business. This research's aims are to determine the effect of direct compensation towards employee performance, and know how to improve the employee performance through direct compensation front office department in St. Regis Bali Resort, based on theory of Mangkunegara and Bangun. The data of this research was collected through distributing online questionnaire, conducting interview, and observing the secondary data. In order to validate the data, data triangulation and SPSS are used when testing the data. The data analysis used are simple linear regression test, t-test, and coefficient determinant test. As the result of the research, there is a positive and significant effect of direct compensation on employee performance in Front Office Department at St. Regis Bali Resort. Thus, knowing the effectof direct compensation towards employee performance as well as optimizing the direct compensation provided are recommended to be done in order to maintain and improve employee performance.
\end{abstract}

Keywords: Direct Compensation, Employee Performance, St. Regis Bali Resort.

\begin{abstract}
Abstrak
Menganalisis pengaruh kompensasi langsung terhadap kinerja karyawan sangat penting untuk setiap bisnis terutama bisnis perhotelan. Penelitian ini bertujuan untuk mengetahui pengaruh kompensasi langsung terhadap kinerja karyawan, dan mengetahui bagaimana meningkatkan kinerja karyawan melalui kompensasi langsung front office department di St. Regis Bali Resort, berdasarkan teori Mangkunegara dan Bangun. Pengumpulan data dalam penelitian ini dilakukan melalui penyebaran kuesioner online, wawancara, dan observasi data sekunder. Untuk memvalidasi data digunakan triangulasi data dan SPSS pada saat pengujian data. Analisis data yang digunakan adalah uji regresi linier sederhana, uji t, dan uji koefisien determinan. Hasil penelitian menunjukkan bahwa terdapat pengaruh yang positif dan signifikan kompensasi langsung terhadap kinerja karyawan pada Front Office Department di St. Regis Bali Resort. Oleh karena itu, mengetahui pengaruh kompensasi langsung terhadap kinerja karyawan serta mengoptimalkan kompensasi langsung yang diberikan disarankan untuk dilakukan dalam rangka mempertahankan dan meningkatkan kinerja karyawan.
\end{abstract}

Kata kunci: Kompensasi Langsung, Kinerja Karyawan, St. Regis Bali Resort. 


\section{A. INTRODUCTION}

St. Regis Bali is a five-star hotel Bali under Marriott's management that provides luxury service towards its guest, which takes human resources management as their concern, to be able to compete with other competitors. The form of human resources as the management and guests can be seen is towards employee performance. Employee performance can be defined as the way employee fulfill their job, responsibility, and execute their required duty or task. According to (Bangun, 2012) a job has certain requirements to be made in achieving the objective referred as a standard job. The job will be indicators of analyzing the employee performance. According to (Mangkunegara, 2016) performance is the result of the quality and quantity of work accomplished by an employee in performing their duties in accordance with the responsibilities given to them.

At this point, since front office become the first impression of the hotel, then knowing the employee performance in front office and providing improvement towards the employee performance in order to provide best service to the guest. This phenomenon will make the hotel be able to compete with the competitors which are the other 5 stars hotel in Nusa Dua Area such as The Mulia Bali Hotel, SOFITEL Bali Nusa Dua, Westin Bali Resort, and Shangrila Hotel. From the hotel's management point of view, the employee performance in term of guest service is increasing represent by guest reviews in front office department (Parsika, 2020). This can be proven by there are many good reviews of the guest related to the employee performance in front office department that is written in Online Travel Agent by customer, such as professional front desk team, very helpful front office staff, and good arrival service (TripAdvisor, 2020). As an addition, St. Regis Asia Pacific Regional Office is expecting the performance of the employee of Front Office department at the St. Regis Bali during the period of January-December 2019are 4.5 of 5 total score (Parsika, 2020), thus, maintaining and improving the employee performance in Front Office department is needed.

One of the main concerns of human resource management that represent Marriot's brand value is providing a good compensation towards its employee, where the compensation plays important roles in affecting the employee performance (Parsika, 2020). Direct compensation can be defined as a company's remuneration given to employees for giving achievement to the company. According to (Sinambela, 2016) direct or financial compensation usually limited to the direct cash benefits that employee receive on monthly or weekly basis for the service they render as employee of a particular organization.

Direct compensation become one of the factors for the employee to provide a maximal effort in doing their job. Based on the interview conducted with Human Resource Director in St. Regis Bali, stated that the hotel would like to analyze the effect of compensation that has been given towards employee performance at St Regis from employee perspective, as a reference for making decisions related to compensation and employee performance in the future (Parsika, 2020)..

There are two main theoretical frameworks used for this research, those are (Mangkunegara, 2016) for the direct compensation theory, and (Bangun, 2012) for the employee performance theory. Direct or financial compensation usually limited to the direct cash benefits that employee receive on monthly or weekly basis for the service they render as employee of a particular organization (Sinambela, 2016). According to (Hoare, 2015) there are 3 types of direct compensation those are salary, commission, and bonuses. Salary is the amount received by the employee in exchange of the work done by employee for a certain period say a day, a week, a month. It is the money an employee receives from the employer by rendering their services. Commission-based pay is most common in sales and is paid out as a percentage of goals met (or quota). Typically, the amount of commission paid increases as the goal increases. Bonuses are compensation for employees for work performed; they are paid in addition to salary or wages. Bonuses are considered compensation if (per the IRS) they "arise out of an employment relationship or are associated with the performance of services." According to (Mangkunegara, 2016) the direct 
compensation indicators are payment level, payment structure, determination of the individual fee, and payment method. Payment level can be defined as a payment that is provided by the company in accordance of the employee ability or position and the ability of the company itself. Payment structure can be defined as a structure of payment that is provided or owned by a company. Determination of individual fee refers to a how an employee determines their obtained fee from the company. Payment method can be defined as a method of payment that is offered by the company. It could be in form of cash or bank transfer.

According to (Campbell, 2012) employee performance relates to the act of doing a job. Job performance is a means to reach a goal or set of goals within a job, role, or organization. According to (Mangkunegara, 2016) performance is the result of the quality and quantity of work accomplished by an employee in performing their duties in accordance with the responsibilities given to them. According to (Bangun, 2012) a job has certain requirements to be made in achieving the objective referred as astandard job. The job will be indicators of analyzing the employee performance. According to (Bangun, 2012) the indicators of employee performance are number of jobs, quality work, punctuality, work absence, and cooperation ability. Number of jobs can be defined as the amount of jobs that is assigned for the employee. Quality works refers to the ability of the employee to maintain their quality work. Punctuality refers to completing a job on time, punctuality shows the effectiveness of time allocation. Work absence refers to the presence of the employee. Co-operation ability refers to the ability of the employee to work with their co-workers.

There are some previous researches that have similar topic with this research which is the effect of direct compensation towards employee performance (see Table 1). Research conducted by Muhammad Arif, Putri Endah Syaifani, Yudi Siswadi, Jufrizen (2019) that focusing on effect of compensation and discipline on employee performance, research conducted by Agung Surya Dwianto (2019) that focusing on the effect of compensation on employee performance at PT. Sango Indonesia - Karawang, and research conducted by Rusman Hidayat (2019) that focusing the effect of motivation and compensation on employee performance.

Table 1 Summary of Research Model used from the Previous Research

\begin{tabular}{lll}
\multicolumn{1}{c}{ Author } & \multicolumn{1}{c}{$\begin{array}{c}\text { Direct } \\
\text { Compensation }\end{array}$} & Employee Performance \\
\hline $\begin{array}{l}\text { Muhammad Arif, } \\
\text { Putri Endah } \\
\text { Syaifani, Yudi } \\
\text { Siswadi, Jufrizen } \\
\text { (2019) }\end{array}$ & Mangkunegara (2004) & Bangun W. (2012) \\
$\begin{array}{l}\text { Agung Surya } \\
\text { Dwianto (2019) }\end{array}$ & Hasibuan (2012: 122) & Wilson Bangun (2012) \\
$\begin{array}{l}\text { Rusman Hidayat } \\
\text { (2019) }\end{array}$ & Kadarisman (2016) & Wilson Bangun (2012) \\
\hline
\end{tabular}

Source: (Muhammad Arif, 2019) (Dwianto, 2019) (Hidayat, 2019)

From those researches, this research is this research is using (Mangkunegara, 2016) and (Bangun, 2012) for the main theory, because those theory is popular among researcher in Indonesia with the same variables and in line with and the topic of this research. The objectives of this research are examining the effect of direct compensations towards employee performance at The St. Regis Bali Resort and know how to maintain the employee performance through optimizing the direct compensation front office 
department in St. Regis Bali Resort. The problem that will be examined in this research are scoped to direct compensation has been given to employee and employee performance, and limited to examine the Front Office department employee perspective. As an addition, this research is expected to help St. Regis hotel to maintain the employee performance through optimizing the direct compensation.

\section{B. RESEARCH METHODS}

The method of this research is mixed method, means combing qualitative and quantitative methods. This method helps the author to expand and strengthen the research's discussion and conclusion. The data that will be collected in form of qualitative and quantitative data. The qualitative data of this research are detail information about St. Regis Hotel, direct compensation provided, guest review, and interview result. While the quantitative data of this method are number of front office employees, and respond of the questionnaire about the direct compensation provided and employee performance.

For the data, this research uses primary and secondary data. Primary data that is used in this research will be collected by doing interview and questionnaire which is related to the employee point of view about the direct compensation, and employee performance. Secondary data that is used in this data will be collected by organizational record from St. Regis Bali itself such as number of employees in front office, types of direct compensation provided, and guest review on Online Travel Agent. Since this research is conducted during the COVID-19 pandemic, then the questionnaire and interview is done through online questionnaire method (Google Form). According to Focus Group Discussion with the hospitality senior practitioners, most of the hotels in Bali are closed during the COVID-19 pandemic including St. Regis Bali, and the employees are provided day off until the specified time. Therefore, the author uses online method in collecting the data.

The population of this research is the all of employee of front office department which is 15 people. Since the population is small, then sampling method that is used is census. This sampling method is using all of the population become the sample, and easy to be used when the population is small. As an addition, the data analysis technique that will be used in this research are qualitative and quantitative data analysis. Qualitative data analysis technique used is descriptive data analysis. Quantitative data analysis technique used are Likert scale, validity test, reliability test, simple linear regression test, t-test, and determinant coefficient test.

\section{RESULT AND ANALYSIS}

\section{Data description}

In this section, the results of the questionnaire in the form of respondents' characteristics are explained. The questionnaire was distributed to 15 respondents with the results of 15 questionnaires that returned and were worthy of research. Characteristics of respondents were classified based on age, educational background and length of service, as stated in table 2 .

Table 2 shows that most employees in the Front Office Department in St. Regis Bali Resort is with an age range of 31 - above years which is as many as 9 people (60\%), the employees with age range 21 30 is only 6 people (40\%). For educational background, 8 employees (54\%) are bachelor degree, while the rest 7 employees (46\%) are diploma degree. Most of the employees or as many as 8 employees (54\%) have been working for 1 - 5 years, while the rest 7 employees (46\%) have been working for more than 5 years. 
Table 2 Characteristics of Respondents

\begin{tabular}{|c|c|}
\hline Characteristic & Number (\%) \\
\hline \multicolumn{2}{|l|}{ Age } \\
\hline $21-30$ & $6(40 \%)$ \\
\hline 31 - above & $9(60 \%)$ \\
\hline \multicolumn{2}{|l|}{ Educational Background } \\
\hline Diploma & $7(46 \%)$ \\
\hline Bachelor & $8(54 \%)$ \\
\hline \multicolumn{2}{|l|}{ Length of Service } \\
\hline 1 - 5 years & $8(54 \%)$ \\
\hline above 5 years & $7(46 \%)$ \\
\hline
\end{tabular}

\section{Hypothesis test}

In this research, validity test is implemented in order to measure the validity or suitability of the questionnaire used. Validity test is done by comparing the value of $r$ count with $r$ table. It can be said to be valid if $r$ count $\geq r$ table. Based on (Kurniawan, 2008), the value of $r$ table if the number of respondents is $15=0.514$. The results of the validity test show that the smallest coefficient value obtained from an indicator variable is 0.532 . The biggest coefficient value is 0.912 . The total value of 27 statement items which are indicators of two research variables each totalling 12 for the Direct Compensation variable and 15 for Employee Performance. Then it can be concluded that all questions are valid because they have coefficient values above 0.514 .

After validity test, then we have to perform reliability test. Reliability is the ability of an instrument to show stability and consistency in measuring concepts. The criterion for measuring the reliability test is the Cronbach's Alpha value $>0.6$ then it can be said to be reliable. According to the result of the reliability test, the Cronbach's alpha value of the Direct Compensation variable is 0.895 and Employee Performance 0.920 . All of the mean values are greater than 0.6 , it can be interpreted that all statement items of the two research variables meet the assumptions of data reliability.

The result of the questionnaire is analysed using descriptive statistical analysis by finding the average value (mean) of respondents' scores on statement items of each variable. Since this research uses 5 indicators for each variable as the benchmark in the questionnaire, the calculation will produce 10 mean values. After calculating the mean score, then the value will be categorized by using interval class formula. This aims to interpret the values in the form of numbers into words. Thus, the result will be easier to be understood. The data calculation is summarized in table 3 . 
Table 3 Data Calculation

\begin{tabular}{ll}
\hline Indicator & $\begin{array}{l}\text { Mean } \\
\text { Score }\end{array}$ \\
\hline Direct Compensation (X) & \\
$\quad$ Payment level & 4.11 \\
$\quad$ Payment structure & 4.00 \\
$\quad \begin{array}{l}\text { Determination of individual } \\
\text { fee }\end{array}$ & 4.23 \\
$\quad$ Payment method & 4.35 \\
Employee Performance (Y) & \\
$\quad$ Number of Jobs & 4.55 \\
Quality of Work & 4.33 \\
Punctuality & 4.35 \\
Attendance & 4.28 \\
Ability Cooperation & 4.53 \\
\hline
\end{tabular}

\section{Source: Primary Data}

Those indicators are represented by 27 statements within the questionnaire that has been distributed. The questionnaires are distributed to the respondents to be answered by assessing the statements from 1 (Strongly disagree) until 5 (Strongly agree). By looking at the mean score calculation and the interval class, it can be seen that the lowest scores are obtained by Payment Structure, Payment level, and Attendance. These scores indicate that those indicators that got lowest scores are not good enough based on employee perspective and need to be improved.

Table4 Score for Payment Structure

\begin{tabular}{lc}
\hline \multicolumn{1}{c}{ Indicators } & Mean Score \\
\hline $\begin{array}{l}\text { Payment Structure } \\
\text { I feel happy because the company kept the } \\
\text { promise to raise the salary in accordance with the } \\
\text { promised amount }\end{array}$ & 4.13 \\
I was satisfied with the amount of the bonus and \\
commission provided
\end{tabular}


Table 5 Cross tabulation Payment Structure

\begin{tabular}{|c|c|c|c|c|c|c|c|c|}
\hline \multirow[b]{2}{*}{ Statements } & \multicolumn{2}{|c|}{$\begin{array}{c}\text { Characteristic } \\
\text { s } \\
\end{array}$} & \multicolumn{6}{|c|}{ Likert Scale } \\
\hline & Age & Gender & 1 & 2 & 3 & 4 & 5 & $\begin{array}{c}\text { Total } \\
\text { Employee }\end{array}$ \\
\hline \multirow{6}{*}{$\begin{array}{c}\text { I was satisfied with the cut of } \\
\text { salary to pay the insurance and } \\
\text { pension program provided by the } \\
\text { hotel }\end{array}$} & $21-$ & Male & - & - & 1 & 1 & - & 2 \\
\hline & 30 & Female & - & - & 1 & 3 & - & 4 \\
\hline & & $\%$ & & & $\begin{array}{c}33 . \\
3\end{array}$ & $\begin{array}{c}66 . \\
7\end{array}$ & & 40 \\
\hline & $31-$ & Male & - & - & 1 & 4 & 1 & 6 \\
\hline & 40 & Female & - & - & 1 & 2 & - & 3 \\
\hline & & $\%$ & & & $\begin{array}{c}22 . \\
2 \\
\end{array}$ & $\begin{array}{c}66 . \\
7 \\
\end{array}$ & $\begin{array}{r}11 \\
.1 \\
\end{array}$ & 60 \\
\hline Total Score & & & - & - & 4 & 10 & 1 & \\
\hline Total \% & & & & & $\begin{array}{c}26 . \\
7\end{array}$ & $\begin{array}{c}66 . \\
7 \\
\end{array}$ & $\begin{array}{l}6 . \\
6 \\
\end{array}$ & 100 \\
\hline
\end{tabular}

Source: Primary Data

Based on the cross-tabulation table 5, it shows that there are 1 male and 1 female employees from 6 total employees at age range 21-30 who are giving neutral score which is 3 . According to the interview of the respondent, the reason is that the they don't care about the financial and pension program as per stated by them that they are still young and fit. Also, for the pension program is still far away looking at their age which are below 30, so they feel they don't need pension program at this time.

On the second statement, there are 6 employees who giving agree and 1 employee who giving strongly agree score from 9 total employees at age range 31-40. This indicates that they are agree and satisfied with the salary cut program to pay insurance and pension program. According to the interview, the employee satisfied and happy with the amount salary cut. Because to them, insurance and pension program is important at this time referring to their age which are above 30. As an addition, the employees already have family. Thus, they think having a good insurance and pension program is very important.

In order to respond this condition, author already interview the Human Resource Director of St. Regis Bali Resort. This interview has a purpose to know the reason why the management of the hotel provide $10 \%$ salary cut. According to the interview, the hotel is more focus on indirect compensation such as insurance, pension program, and loss and breakage. Also, the hotel generalizing the bonus and commission in order to provide the bonus and commission equally. The employee expects the percentage of the salary cut is below $10 \%$ and the bonus and commission given to the employee according to their performance. Thus, the employee will be more motivated in performing their job (Parsika, 2020).

As stated by (Mangkunegara, 2016) it is logical that employees and employers alike view money as the fundamental incentive for satisfactory job performance. If looking at the scores given, the payment structure provided by the hotel is already effective. This will be beneficial for both the management and employees, as the payment structure provided are applied efficiently and effectively 
Table 6 Score for Payment Level

\begin{tabular}{lc}
\hline \multicolumn{1}{c}{ Indicators } & $\begin{array}{l}\text { Mean } \\
\text { Score }\end{array}$ \\
\hline Payment Structure & \\
\multicolumn{1}{c}{$\begin{array}{l}\text { I was satisfied with the level of payment } \\
\text { of direct compensation that I received }\end{array}$} & 4.27 \\
$\begin{array}{l}\text { I feel I have received my direct } \\
\text { compensation in accordance with the } \\
\text { level of ability of the hotel }\end{array}$ & 3.93 \\
$\begin{array}{l}\text { I have received service fee more than I } \\
\text { expected }\end{array}$ & 4.13 \\
\hline & Source: Primary Data
\end{tabular}

Table 7 Cross tabulation Payment Level

\begin{tabular}{|c|c|c|c|c|c|c|c|c|}
\hline \multirow{2}{*}{ Statements } & \multicolumn{2}{|c|}{$\begin{array}{c}\text { Characteristic } \\
\text { s }\end{array}$} & \multicolumn{6}{|c|}{ Likert Scale } \\
\hline & Age & Gender & 1 & 2 & 3 & 4 & 5 & $\begin{array}{c}\text { Total } \\
\text { Employee }\end{array}$ \\
\hline \multirow{7}{*}{$\begin{array}{l}\text { I feel I have received my } \\
\text { direct compensation in } \\
\text { accordance with the level } \\
\text { of ability of the hotel }\end{array}$} & $21-$ & Male & - & - & 1 & 1 & - & 2 \\
\hline & 30 & Female & - & - & 2 & 1 & 1 & 4 \\
\hline & & $\%$ & & & 50 & 33. & 16. & 40 \\
\hline & & & & & & 3 & 7 & \\
\hline & $31-$ & Male & - & - & 2 & - & 4 & 6 \\
\hline & $>40$ & Female & - & - & 1 & 2 & - & 3 \\
\hline & & $\%$ & & & $\begin{array}{c}33 . \\
3\end{array}$ & $\begin{array}{c}22 . \\
2\end{array}$ & $\begin{array}{c}44 . \\
5 \\
\end{array}$ & 60 \\
\hline \multicolumn{2}{|c|}{ Total Score } & & & & 6 & 4 & 5 & 15 \\
\hline \multicolumn{2}{|l|}{ Total \% } & & & & 40 & $\begin{array}{c}26 . \\
7\end{array}$ & $\begin{array}{c}33 . \\
3\end{array}$ & 100 \\
\hline
\end{tabular}

\section{Source: Primary Data}

Based on the cross-tabulation table 7, it shows that there are 1 male and 1 female employees from 6 total employees at age range 21-30 who are giving neutral score which is 3. According to the interview of the respondent, the reason is that the they don't care about the financial and pension program as per stated by them that they are still young and fit. Also, for the pension program is still far away looking at their age which are below 30, so they feel they don't need pension program at this time.

On the second statement, there are 6 employees who giving agree and 1 employee who giving strongly agree score from 9 total employees at age range 31-40. This indicates that they are agree and satisfied with the salary cut program to pay insurance and pension program. According to the interview, the employee satisfied and happy with the amount salary cut. Because to them, insurance and pension program is important at this time referring to their age which are above 30. As an addition, the employees already have family. Thus, they think having a good insurance and pension program is very important.

In order to respond this condition, author already interview the Human Resource Director of St. Regis Bali Resort. This interview has a purpose to know the reason why the management of the hotel 
provide $10 \%$ salary cut. According to the interview, the hotel is more focus on indirect compensation such as insurance, pension program, and loss and breakage. Also, the hotel generalizing the bonus and commission in order to provide the bonus and commission equally. The employee expects the percentage of the salary cut is below $10 \%$ and the bonus and commission given to the employee according to their performance. Thus, the employee will be more motivated in performing their job (Parsika, 2020).

As stated by (Mangkunegara, 2016) it is logical that employees and employers alike view money as the fundamental incentive for satisfactory job performance. If looking at the scores given, the payment structure provided by the hotel is already effective. This will be beneficial for both the management and employees, as the payment structure provided are applied efficiently and effectively.

Table 8 Score for Payment Level

\begin{tabular}{lc}
\hline \multicolumn{1}{c}{ Indicators } & $\begin{array}{c}\text { Mean } \\
\text { Score }\end{array}$ \\
\hline $\begin{array}{l}\text { Payment Structure } \\
\text { I was satisfied with the level of } \\
\text { payment of direct compensation that } \\
\begin{array}{l}\text { I received } \\
\text { I feel I have received my direct } \\
\text { compensation in accordance with } \\
\text { the level of ability of the hotel }\end{array}\end{array}$ & 4.27 \\
$\begin{array}{l}\text { I have received service fee more than } \\
\text { I expected }\end{array}$ & 3.93 \\
\hline \multicolumn{1}{c}{ Source: Primary Data } \\
\hline
\end{tabular}

Table 9 Cross tabulation Payment Level

\begin{tabular}{|c|c|c|c|c|c|c|c|c|}
\hline \multirow{2}{*}{ Statements } & \multicolumn{2}{|c|}{$\begin{array}{c}\text { Characteristic } \\
\text { s } \\
\end{array}$} & \multicolumn{6}{|c|}{ Likert Scale } \\
\hline & Age & Gender & 1 & 2 & 3 & 4 & 5 & $\begin{array}{c}\text { Total } \\
\text { Employee }\end{array}$ \\
\hline \multirow{6}{*}{$\begin{array}{l}\text { I feel I have } \\
\text { received my direct } \\
\text { compensation in } \\
\text { accordance with } \\
\text { the level of ability } \\
\text { of the hotel }\end{array}$} & $21-$ & Male & - & - & 1 & 1 & - & 2 \\
\hline & 30 & Female & - & - & 2 & 1 & 1 & 4 \\
\hline & & $\%$ & & & 50 & $\begin{array}{c}33 . \\
3\end{array}$ & $\begin{array}{c}16 . \\
7 \\
\end{array}$ & 40 \\
\hline & $31-$ & Male & - & - & 2 & - & 4 & 6 \\
\hline & $>40$ & Female & - & - & 1 & 2 & - & 3 \\
\hline & & $\%$ & & & $\begin{array}{c}33 . \\
3\end{array}$ & $\begin{array}{c}22 . \\
2\end{array}$ & $\begin{array}{r}44 . \\
5\end{array}$ & 60 \\
\hline \multicolumn{3}{|c|}{ Total Score } & & & 6 & 4 & 5 & 15 \\
\hline \multicolumn{3}{|c|}{ Total \% } & & & 40 & $\begin{array}{c}26 . \\
7\end{array}$ & $\begin{array}{c}33 \\
3\end{array}$ & 100 \\
\hline
\end{tabular}

Source: Primary Data

Based on the cross-tabulation table 8 and table 9, there are 1 male and 2 female employees from 6 total employees at age range 21-30 who are giving neutral score which is 3. According to the interview with the respondent, the reason why they give neutral score is that they feel that their direct compensation already equal with their level, position, and educational background. Also, the employee at age range 2130 is already worked for one and a half year. However, they also wondering that the direct compensation provided by the hotel is already in accordance of the hotel's ability or not. 
For the second statement, there are 4 total employees who are giving strongly agree and 2 employees who are giving agree score from 6 total employees at age range 31-40. This indicates that they are agree with the payment level they got. According to the interview of the respondent, the reason why they are satisfied because the amount of the direct compensation provided, also since they already have worked for several years, they know about the ability of the hotel such as rated as a 5 stars hotel that win numerous nominees. To them, the amount of the direct compensation provide by the hotel is already in accordance with the hotel ability.

In order to respond the situation, the author already interview the Human Resource Director of St. Regis Bali Resort. This interview has a purpose to respond the issue that most of the employee neutral in their thought about the direct compensation is in accordance of the ability of the hotel. According to the interview, the hotel already provides both direct compensation and indirect compensation. This issue might be caused that the number of indirect compensations is bigger than the direct compensation such as, health insurance, AIA insurance, pension program, and outing program (Parsika, 2020).

Comparing to the theory of (Bangun, 2012) that it is logical that employees and employers alike view money as the fundamental incentive for satisfactory job performance. If looking at the scores given, the payment level provided by the hotel is already effective. However, the management should be updated in providing the direct compensation in accordance of the ability of the hotel. If the hotel is growing up then the ability of the hotel will be growing up too. Thus, this phenomenon should be considered by the management to respond the issue occurs.

The rest indicators such as determination of individual fee and payment method is in good condition. This can be proven by the number of the score given by the respondent, are above 4.2. This indicates that the determination and payment indicators are agreed or accepted by the employees. Means that the employees are satisfied with the determination of individual fee and payment method indicators. For the determination of individual fee, the employee gives 4 scores. According to the interview with one of the respondents, the employee feel that their direct compensation is according their education level, length of service, and direct compensation is in line with the workload. For the payment method, the employees give 4 scores also. According to the interview with one of the respondents, the payment method offered by the hotel is already accepted by the employees which is bank transfer payment method. Besides, the direct compensation is provided in an appropriate time, which is fixed in certain date (Maryuda, 2020).

Table 10 Score for Attendance

\begin{tabular}{lc}
\multicolumn{1}{c}{ Indicators } & $\begin{array}{l}\text { Mean } \\
\text { Score }\end{array}$ \\
\hline Payment Structure & \\
$\quad \begin{array}{l}\text { I never leave work earlier while in } \\
\text { working time }\end{array}$ & 4.33 \\
$\begin{array}{l}\text { I arrived on or in time according the } \\
\text { working hour }\end{array}$ & 4.20 \\
$\begin{array}{l}\text { My presence is never empty every } \\
\text { week }\end{array}$ & 4.33 \\
\hline
\end{tabular}


Table 11 Cross tabulation Payment Level

\begin{tabular}{|c|c|c|c|c|c|c|c|c|}
\hline \multirow{2}{*}{ Statements } & \multicolumn{2}{|c|}{$\begin{array}{c}\text { Characteristic } \\
\text { s }\end{array}$} & \multicolumn{6}{|c|}{ Likert Scale } \\
\hline & Age & Gender & 1 & 2 & 3 & 4 & 5 & $\begin{array}{c}\text { Total } \\
\text { Employee }\end{array}$ \\
\hline \multirow{6}{*}{$\begin{array}{l}\text { I arrived on } \\
\text { or in time } \\
\text { according the } \\
\text { working hour }\end{array}$} & $21-$ & Male & - & - & - & 3 & - & 3 \\
\hline & 30 & Female & - & - & - & 2 & 1 & 3 \\
\hline & & $\%$ & & & & $\begin{array}{c}33 . \\
3\end{array}$ & $\begin{array}{c}16 . \\
7\end{array}$ & 40 \\
\hline & $31-$ & Male & - & - & - & 4 & 2 & 6 \\
\hline & $>40$ & Female & - & - & - & 3 & - & 3 \\
\hline & & $\%$ & & & & $\begin{array}{c}22 . \\
2\end{array}$ & $\begin{array}{c}44 . \\
5\end{array}$ & 60 \\
\hline \multicolumn{3}{|c|}{ Total Score } & & & & 12 & 3 & 15 \\
\hline \multicolumn{3}{|c|}{ Total \% } & & & & 80 & 20 & 100 \\
\hline
\end{tabular}

Source: Primary Data

Based on the cross-tabulation table 11, it shows that there are 3 male and 2 female employees from 6 total employees at age range 21-30 who are giving agree score which is 4 . According to the interview to the one of the respondents, most of the staff is stay far away from the hotel. As an addition, the working hour of the Front Office Department is flexible, which means that if the occupancy rate is high then the staff should be there as soon as possible, while the occupancy rate is low, the staff may leave earlier (Maryuda, 2020).

On the second statement, there are 7 employees who giving agree and 2 employee who giving strongly agree score from 9 total employees at age range 31-40. This indicates that they are agree and satisfied with the statement about arrived on or in time according with the working hour. Same as the interview above, since the working hour is flexible, then this will make them can answer 5.

Considering that the participant gave high scores on this indicator, it indicates that the situation is already ideal and in line with the theory stated by (Bangun, 2012). In the theory stated that the attendance is really necessary to influence the working results done by the employee.

The rest indicators such as number of jobs, quality of works, punctuality, and co-operation ability is in good condition. This can be proven by the number of the score given by the respondent, are above 4.3. This indicates that the employee performance in term of those indicators are great, means the employees are able to perform those indicators properly. For the number of jobs indicators, the employee are giving 5 scores, which indicates they are satisfied with the number of jobs assigned. According to the interview with one of the respondents, the employees are able to settle the amount of work assigned properly and able to do more than one job. For the quality of works, the employees also giving 5 scores. According to the interview with one of the respondents, most of the employees are able to complete the work in accordance with the expectations of the leadership. For the punctuality indicators, most of the employees giving 4 scores, which indicates this indicator is good for employee point of view. According to the interview of one of the respondents, employees are able to finish the work on time and have no problem with the overtime. For the ability to co-operate indicator, most of the employee give 5 score. The reason is that employees work atmosphere is like a family, appreciate each other, and having good communication to each other (Maryuda, 2020).

Even though the attendance has a good score also. However, comparing to all of the total score per indicators. The attendance is the lowest than the other. This situation makes the author only focusing the attendance only.

34 | Barista: Jurnal Kajian Bahasa dan Pariwisata, Volume 7 Nomor 1, 2020: 24-38 
Table 12 Result of simple linear regression analysis using SPSS Version 23

\begin{tabular}{|c|c|c|c|c|c|}
\hline \multicolumn{6}{|c|}{ Coefficients $^{a}$} \\
\hline \multirow[b]{2}{*}{ Model } & \multicolumn{2}{|c|}{$\begin{array}{c}\text { Unstandardized } \\
\text { Coefficients }\end{array}$} & \multirow{2}{*}{$\begin{array}{c}\text { Standardized } \\
\text { Coefficients } \\
\text { Beta } \\
\end{array}$} & \multirow[b]{2}{*}{$t$} & \multirow[b]{2}{*}{ Sig. } \\
\hline & $B$ & Std. Error & & & \\
\hline $\begin{array}{ll}1 & \text { (Constant) }\end{array}$ & 24,375 & 8,218 & & $\begin{array}{r}2,96 \\
6\end{array}$ &, 011 \\
\hline Direct Compensation & ,913 & ,180 & ,815 & $\begin{array}{r}5,07 \\
9\end{array}$ & 000 \\
\hline
\end{tabular}

Data calculation and analysis is performed using SPSS version 23 for Windows statistics. After using SPSS, processed results will be obtained which will be explained in order to obtain a conclusion. The recapitulation of SPSS version 23 analysis can be seen in Table 12 .

In Table 12 it can be seen that the constant value is 24.375 and the Direct Compensation regression coefficient is 0.913 . Based on the constant value and the value of the regression coefficient of each independent variable, the simple linear regression equation is obtained as follows;

$$
\mathrm{Y}=24.375+0.913 \mathrm{X}
$$

Based on calculations with the formula $\mathrm{Y}=\mathrm{a}+\mathrm{b}$ obtained by simple linear regression equation provides information that: A constant value of 24.375 means that if the Direct Compensation variable is omitted, then the Employee Performance is worth 24,375. When the value of the independent variable (Direct Compensation) increases, the dependent variable (Employee Performance) will increase. The value of the regression coefficient of the Direct Compensation variable against Employee Performance is 0.913, meaning that if Direct Compensation has increased by one unit, while the other variables remain, the Employee Performance will increase by 0.913 . The Direct Compensation coefficient is positive, meaning that between Direct Compensation and Employee Performance has a positive relationship. An increase in Direct Compensation will result in an increase in Employee Performance.

T Test. This test is carried out to determine the significance of the influence of the independent variable (Direct Compensation) on the dependent variable (Employee Performance). The basis of making this $t$ test consists of two considerations, namely the comparison of the value of $t$ arithmetic with $t$ table and based on the significance value. A t test is carried out, the results of which can be seen in Table 7 below.

Table 13 Result of $t$ test

\begin{tabular}{lccc}
\hline \multicolumn{1}{c}{ Variable } & t-count & Sig & Information \\
\hline Direct Compensation $(\mathrm{X})$ & 5,079 & 0,000 & Positive and Significant \\
\hline Alpha $(\alpha) 0,05$ & & & \\
\hline Hypothesis test & & \\
Ho: Direct Compensation has no significant effect on Employee Performance. \\
Ha: Direct Compensation has a significant effect on Employee Performance.
\end{tabular}

Based on Table 13, it can be seen that the value of Direct Compensation $(X)$ is 5,079 with a significance of less than the value $(0,000<0.05)$.

Determining the value of ttable.

The level of significance used in this test is 0.05 or (trust level) $=5 \%$ with a degree of freedom $\mathrm{df}=$ $\mathrm{n}-\mathrm{k}$. Value of $\mathrm{n}=15$ and $\mathrm{k}=2$, then $\mathrm{df}=15-2=13$. The size of ttable $=\mathrm{t}$ (, df) so the value sought is $\mathrm{t}(0.05$; 13). Based on (Kurniawan, 2008), the value of t table $=1.771$.

Comparing the value of $t$ count with ttable 
If $\mathrm{t}$ count $>\mathrm{t}$ table or significance value $<\alpha$ then $\mathrm{H} 0$ is rejected and Ha is accepted.

If $t$ count $<t$ table or significance value $>\alpha$ then $\mathrm{HO}$ is accepted and Ha is rejected.

Figure 1 t Test Distribution Curve Testing Training Coefficient (X) on Employee Performance (Y)

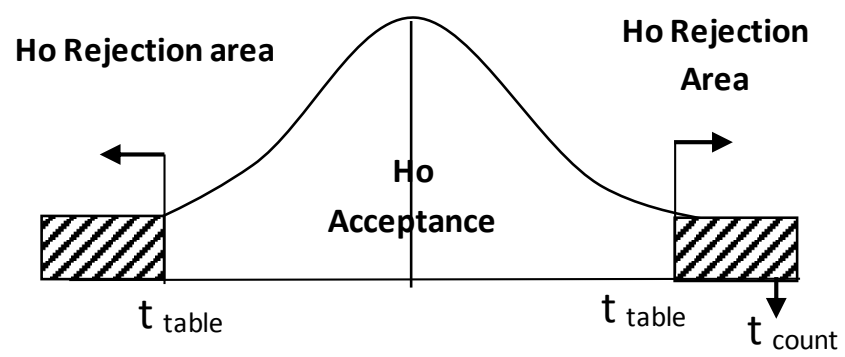

Figure 1 shows that $t$ count $>t$ table $=5,079>1,771$ and the significance value $<=0,000<0.05$ then Ho is rejected and Ha is accepted. This shows that Direct Compensation has a positive and significant effect on Front Office Employee Performance in St. Regis Bali with an error rate of 5\%, 95\% confidence and a degree offreedom 13.

The coefficient of determination analysis aims to find out the magnitude of influence in the form of a percentage for the variable under study, namely the Direct Compensation $(X)$ variable against the Employee Performance (Y) variable. The following Table 4.12 shows the results of the calculation of the coefficient of determination analysis.

Table 14 Result of Coefficient Determinant Test

\begin{tabular}{|ll|c|r|r|}
\hline \multicolumn{9}{|c|}{ Model Summary } \\
& & $R$ & Adjusted $R$ & Std.Error of \\
Model & $R$ & Square & Square & the Estimate \\
\hline 1 &, $815^{a}$ &, 665 &, 639 & 2,92962 \\
\hline a. Predictors: (Constant), Direct Compensation \\
\hline \multicolumn{4}{|c}{ Source: Primary data. }
\end{tabular}

Here is Table 14 which shows the results of the calculation of the coefficient of determination by looking at the R square value obtained from the results of the analysis is 0.486 . Calculation of the coefficient of determination test results above mean that the dependent variable can be explained by the independent variables as much as $66.5 \%(0.665 \times 100 \%)$, the rest of $33.5 \%(100 \%-66.5 \%)$ are explained by other variables not used in this study. Many other factors outside of Direct Compensation that can affect Employee Performance such as the ability of employees themselves, work motivation, support from superiors, work environment and relationships with the organization.

After knowing the positive result of the effect of direct compensation towards employee performance in Front Office Department at St. Regis Bali, the next step is describing the way to improve employee performance through optimizing the direct compensations. The reason is even though the result of this research is good in overall, the improvement is needed. The improvement will be proposed according to the indicators that have low score of Direct Compensation $(\mathrm{X})$ that researched. 
Table 15 The Way to Improve Employee Performance through Optimizing Direct Compensation

\begin{tabular}{|c|c|c|}
\hline Indicators & Improvements & Notes \\
\hline Payment Level & $\begin{array}{l}\text { The hotel should update their } \\
\text { ability and achievement once } \\
\text { for a semester to and } \\
\text { transparent for the direct } \\
\text { compensation since the hotel } \\
\text { is growing up. Means that } \\
\text { level of the direct } \\
\text { compensation should be } \\
\text { following the ability of the } \\
\text { hotel. }\end{array}$ & $\begin{array}{l}\text { This is urgent to be improved } \\
\text { as the score is low. }\end{array}$ \\
\hline Payment Structure & $\begin{array}{l}\text { Providing the information } \\
\text { how important the insurance } \\
\text { and pension program towards } \\
\text { the employee, so the } \\
\text { employee will feel that the } \\
\text { amount of the salary gotten is } \\
\text { equal to their job. }\end{array}$ & $\begin{array}{l}\text { This is urgent to be improved } \\
\text { as the score is low. }\end{array}$ \\
\hline $\begin{array}{l}\text { Determination of Individual } \\
\text { Fee }\end{array}$ & $\begin{array}{l}\text { The hotel should maintain the } \\
\text { direct compensation and } \\
\text { make sure the direct } \\
\text { compensation is equal to their } \\
\text { job and workload. }\end{array}$ & $\begin{array}{l}\text { This aspect can be improved } \\
\text { later. }\end{array}$ \\
\hline Payment Method & $\begin{array}{l}\text { The hotel should maintain the } \\
\text { payment method provided } \\
\text { and also can update the } \\
\text { method of payment if } \\
\text { necessary. Thus, the method } \\
\text { of payment can be variative. }\end{array}$ & $\begin{array}{l}\text { This aspect can be improved } \\
\text { later. }\end{array}$ \\
\hline
\end{tabular}

\section{CONCLUSION}

As a conclusion, the effect of Direct Compensation towards Employee Performance in Front Office Department at St. Regis Bali can be stated positive and have significant effect. This can be proven by regression equation model in this research shows that the direct compensation on employee performance variables have positive relationship.. The percentage of coefficient determinant test is proved that the independent variable (Direct Compensation) has a big effect towards the dependent variable (Employee Performance).

This research is also very important for the hotel since the hotel management through Human Resources department is also wondering the effect of direct compensations that have been provided towards the employee performance, as there is no previous research that has been conducted related to this topic. As an addition, the management hotels want to identify if there is a problem related to dorect compensation provided, and planning a plan for better business progress from optimising the direct compensation.

There are some strength, weakness, opportunity, and challenge in this research. In term of strength of this research, since the method of the research is mixed methods, then the research will be able to provide more complete and detail results rather than using only one method. In term of the weakness, this research is only using one department which is Front Office Department. The reason is that Front Office Department is the first department that have direct contact with the guest. Front Office Department have 
small population which only 15 people if comparing with the other department that has population more than 15 people. So, this will be the weakness of this research. In term of opportunity, in making this research, the researcher is supported with the human resources management and the staff of the Front Office department. As an addition, the author of this research knows the Human Resource Management and a friend of Duty Manager of St. Regis Bali. Thus, in collecting the data, the author will be easier. For the challenge, since this research is conducted when there is a COVID-19 pandemic, which make the St. Regis Bali close all of their operational activities. This situation will make the author should provide big effort in distributing the questionnaire which is using online method that takes a long time to be collected.

As the recommendation, even though the result is positive and significant, there are still improvement needed to improve the indicator of Direct Compensation $(\mathrm{X})$ that have lowest score which are payment level, and payment structure indicators. This can be improved by optimizing these indicators in the St Regis Bali. At this point, the way to improve employee performance through optimizing the direct compensation is optimizing the payment structure and payment level of the direct compensation. Since those indicators have low score than the others. First thing is that the hotel should update the hotel should update their ability and achievement once for a semester to and transparent for the direct compensation since the hotel is growing up. Means that level of the direct compensation should be following the ability of the hotel. The other way that can be done is the management should provide socialization towards their employee about how important is the insurance and pension program for their life. Thus, the employee will realize and accept about the salary cut policy for paying their insurance and pension program. Other point, management could conduct another research regarding effect of direct compensation towards employee performance from management side, then compare it with employee perspective result, so then management could have recommendation on decision making related to direct compensation and employee performance in the future.

\section{References}

Arifin, M., (2017). Pengaruh Kompensasi Dan Kepuasan Kerja Terhadap Kinerja. EduTech : Jurnal Ilmu Pendidikan Dan Ilmu Sosial, 3(2), 87-98.

Bangun, W., (2012). Manajemen Sumber Daya. Jakarta: Erlanga.

Campbell, (2012). Job performance. In: S. H. Neal W. Schmitt, ed. Handbook of psychology, vol. 12: Industrial and organizational psychology. s.l.:Wiley, pp. 82-103.

Hoare, D. J., (2015). Types of direct compensation. Direct Compensation Form, p. 10.

Hoerr, P., (2000). Compensation and work motivation, Consortium for Policy Research in.

Julfrizen, J., (2016). Efek Mediasi Kepuasan Kerja Pada Pengaruh Kompensasi Terhadap Kinerja. Jurnal Ilmiah Manajemen Dan Bisnis.

Kurniawan, D., (2008). Tabel Distribusi. Austria: R. Foundation For Statistical Computing.

Mangkunegara, A. A. A. P., (2016). Manajemen Sumber Daya Manusia Perusahaan. Bandung: Remaja Rosdakarya.

Maryuda, I. P., (2020). FO St. Regis Bali Resort [Interview] (26 February 2020).

Parsika, W., 2020. Human Resources detail [Interview] 2020.

Sastrohadiwiryo, B. S., (2003). Manajemen Tenaga Kerja Indonesia. Jakarta: PT. Bumi Aksara.

Sinambela, L. P., (2016). Manajemen Sumber Daya Manusia. Jakarta: Bumi Aksara, p. 34 .

TripAdvisor, $2020 . \quad$ St. $\quad$ Regis $\quad$ Bali. [Online] Available at: https://www.tripadvisor.co.id/Hotel Review-g297698-d1146351-ReviewsThe St Regis Bali Resort-Nusa Dua Nusa Dua Peninsula Bali.html

[Accessed July 2020]. 